

\title{
Article
}

\section{Transnational Corporate Liability for Environmental Damage and Climate Change: Reassessing Access to Justice after Vedanta v. Lungowe}

\author{
Samvel Varvastian* \& Felicity Kalunga*
}

\begin{abstract}
:
On 10 April 2019, the Supreme Court of the United Kingdom delivered judgment in the case Vedanta v. Lungowe, concerning the liability of an English company for environmental damage caused by its subsidiary in Zambia. The decision confirms that English parent companies can owe a duty of care to foreign claimants affected by operations of their subsidiaries abroad and that the English courts may have jurisdiction to hear such cases even when a foreign court is a more appropriate place for the trial. It establishes an important precedent for providing access to justice for foreign claimants in transnational corporate liability litigation. Given the global presence of English companies, and the fact that their foreign subsidiaries have been involved in multiple cases of environmental damage in the host states, the decision could give an impetus to future claims brought in the English courts. Also, the decision opens some interesting possibilities for climate change liability litigation against English parent companies and their foreign subsidiaries, as their cumulative greenhouse gas emissions would likely be considerably higher than taken separately, arguably making prospective claims against them more viable.
\end{abstract}

Keywords: environmental damage, climate change, litigation, transnational corporate liability, access to justice, human rights

\footnotetext{
${ }^{*}$ Cardiff University, School of Law and Politics, Cardiff (United Kingdom (UK)).

Email:varvastians@cardiff.ac.uk.

${ }^{* *}$ Cardiff University, School of Law and Politics, Cardiff (UK).

Email: kalungafk@cardiff.ac.uk.

A draft version of this paper was presented during a climate litigation workshop organized by the Grantham Research Institute on Climate Change and the Environment at the London School of Economics and Political Science on 21 June 2019. We are grateful to Joana Setzer, Jacqueline Peel, Veerle Heyvaert, Ketan Jha, Geetanjali Ganguly, Javier Solana and Lucy Maxwell for their valuable feedback. We are also grateful to Anna Grear and Valerie Fogleman for their support during the production of this paper. Finally, we would like to thank the anonymous TEL referees for their useful comments.
} 


\section{Introduction}

Widespread environmental degradation and the resulting harms to human communities caused by business operations of large corporate entities are a sad and well-known reality. Exceptionally disastrous and transboundary incidents, such as the Deepwater Horizon oil spill in the Gulf of Mexico, ${ }^{1}$ can attract global media attention and lead to legal scrutiny, revealing the persistent problem of poor safety standards and violation of environmental laws and regulations that seems to permeate corporate culture. ${ }^{2}$ Even more widespread environmental threats that are of truly planetary scale, such as climate change, are also increasingly linked to large corporate entities which had early knowledge of the risks posed by their activities and had opportunities to mitigate those risks, but repeatedly failed to do so or, even worse, tried to mislead the public by spreading misinformation campaigns and lobbying regulators against taking action. ${ }^{3}$

However, while the activities leading or contributing to large-scale environmental damage come under ever-increasing legal scrutiny in developed countries, the same activities can easily go unchecked in developing countries, potentially leaving the most vulnerable groups of local people unprotected. Such people may be unable to pursue litigation due to a lack of funds or experienced lawyers. They may often be employed by, and thus be dependent on, the polluting entity. As if this were not enough, the operations of the polluting entity may be controlled not by a local branch but from an office of its parent company located thousands of miles away. Without any means of protecting themselves in the local courts, the affected communities may thus have only one viable option - to seek justice in the courts of the parent company's home state.

On 10 April 2019, the Supreme Court of the United Kingdom (UK) delivered judgment in exactly such a case, Vedanta v. Lungowe, ${ }^{4}$ which concerns the liability of an English company for environmental damage caused by its foreign subsidiary in Zambia. The decision confirmed that English parent companies could owe a duty of care to foreign claimants affected by operations of their subsidiaries abroad and that the English courts could have jurisdiction to hear such cases even when a foreign court is a more appropriate place for the trial. This finding will likely have a significant impact as many English companies have numerous subsidiaries abroad, and the latter have been involved in multiple cases of environmental damage in the host states. The decision could, therefore, give an impetus to future claims brought in the English courts. Furthermore, apart from its relevance to corporate environmental liability in general, the decision opens some

\footnotetext{
1 In April 2010, the explosion on the Deepwater Horizon oil rig, operated by BP (a British oil and gas multinational corporation (MNC)) led to the largest marine oil spill in history, causing vast environmental damage. See J. Beyer et al., 'Environmental Effects of the Deepwater Horizon Oil Spill: A Review' (2016) 110(1) Marine Pollution Bulletin, pp. 28-51.

2 See, e.g., M.A. Cherry \& J.F. Sneirson, 'Beyond Profit: Rethinking Corporate Social Responsibility and Greenwashing after the BP Oil Disaster' (2010) 85(4) Tulane Law Review, pp. 983-1038, at 984.

${ }^{3}$ See, e.g., Center for International Environmental Law (CIEL), 'Smoke and Fumes: The Legal and Evidentiary Basis for Holding Big Oil Accountable for the Climate Crisis', Nov. 2017, available at: https://www.ciel.org/wp-content/uploads/2019/01/Smoke-Fumes.pdf; G. Supran \& N. Oreskes, 'Assessing ExxonMobil's Climate Change Communications (1977-2014)' (2017) 12(8) Environmental Research Letters, pp. 1-18, at 12-15; P.C. Frumhoff, R. Heede \& N. Oreskes, 'The Climate Responsibilities of Industrial Carbon Producers' (2015) 132(2) Climatic Change, pp. 157-171, at 161-166.

${ }^{4}$ Vedanta Resources PLC and another (Appellants) v. Lungowe and others (Respondents) [2019] UKSC 20, on appeal from: [2017] EWCA Civ 1528 (Vedanta).
} 
interesting possibilities for climate change liability litigation against English parent companies and their foreign subsidiaries, as their cumulative greenhouse gas (GHG) emissions would likely be considerably higher than taken separately, arguably making prospective claims against them more viable.

Part two of this article discusses the case and the reasoning of the English courts in determining jurisdiction. The third part considers the transnational significance of the case by positioning it in the context of similar litigation in England and abroad. The fourth analyzes the relevance of the decision for prospective claims against English companies and their foreign subsidiaries for contributing to climate change. The final part concludes by summarizing some long-term implications of the decision.

\section{Circumstances of the case}

For many years, the Nchanga Copper Mine in the Chingola District of Zambia - allegedly the second largest in the world and the largest private employer in the country - has been discharging toxic emissions into the watercourses used by exceptionally poor members of local rural farming communities for drinking, irrigation and other essential purposes. ${ }^{5}$ The owner of the mine is Konkola Copper Mines plc (KCM), a public company incorporated in Zambia and subsidiary of Vedanta Resources plc (Vedanta) - a multinational group incorporated and domiciled in England. ${ }^{6}$ KCM is not fully owned by Vedanta as the Zambian government has a significant minority stake. ${ }^{7}$ However, according to materials published by Vedanta, the ultimate control of KCM is not 'to be regarded as any less than it would be if wholly owned'. ${ }^{8}$

In 2015, a group of 1826 Zambian citizens initiated proceedings against both KCM and Vedanta before the England and Wales High Court (Technology and Construction Court) alleging personal injury, damage to property and loss of income, amenity and enjoyment of land due to environmental damage caused by discharges from the mine since $2005 .{ }^{9} \mathrm{KCM}$ was sued as the operator of Nchanga Copper Mine. ${ }^{10}$ Vedanta was sued because it maintained high control and direction over the mining operations of KCM and the latter had to comply with health, safety and

\footnotetext{
${ }^{5}$ Dominic Liswaniso Lungowe \& Others v. Vedanta Resources Plc \& Konkola Copper Mines Plc [2016] EWHC 975 (TCC) (Lungowe), para. 12.

${ }^{6}$ Ibid., para. 13. In this article, the term 'England' is used as a shorthand expression for jurisdiction in England and Wales.

${ }^{7}$ At the time of the Supreme Court's decision, Vedanta held nearly $80 \%$ of KCM's shares; the remaining $20 \%$ were held by ZCCM Investment Holdings plc, almost entirely owned by the Zambian government. The latter also had a golden share in KCM. See information on KCM shareholding available at: http://kcm.co.zm/corporate-profile/company-overview/shareholding.

${ }^{8}$ Vedanta, para. 2.

${ }^{9}$ However, as observed by the High Court, 'there are no details about their injuries, their land, or their alleged losses' (Vedanta, para. 11).

${ }^{10}$ Notably, this was not the first time that KCM was sued over its polluting activities. Thus, the initial legal action against KCM dates back to the mid-2000s, when a group of local residents brought a similar lawsuit Nyasulu and 2,000 others v. KCM (2007/HP/1286) before Zambian courts. The case is discussed in more detail below.
} 
environmental standards established by Vedanta. ${ }^{11}$ The claims were based on the common law of negligence, nuisance, trespass and breach of statutory duty in accordance with Zambian law. ${ }^{12}$

\subsection{Jurisdiction}

Both Vedanta and KCM challenged the jurisdiction of the English courts. They asserted that the case did not disclose a real justiciable issue against Vedanta because it could not 'be shown to have done anything in relation to the operation of the Mine sufficient either to give rise to a common law duty of care in favour of the claimants, or a statutory liability as a participant in breaches of Zambian environmental protection, mining and public health legislation'. ${ }^{13}$ Furthermore, the defendants argued that even if a real justiciable issue were disclosed against Vedanta, the case should be dismissed for being an abuse of European Union (EU) law 'because the claimants [were] using a claim against Vedanta in England purely as a vehicle for attracting English jurisdiction against their real target defendant, $\mathrm{KCM},{ }^{14}$ by means of the necessary or proper party gateway' under the Civil Procedure Rules.

The necessary or proper party gateway is provided under Paragraph 3.1(3) of Practice Direction $6 \mathrm{~B}$ of the Court Procedure Rules (CPR), giving the English courts the power to authorize service of process to parties outside the jurisdiction when:

(3) A claim is made against a person ('the defendant') on whom the claim form has been or will be served (otherwise than in reliance on this paragraph) and -

(a) there is between the claimant and the defendant a real issue which it is reasonable for the court to try; and

(b) the claimant wishes to serve the claim form on another person who is a necessary or proper party to that claim.

Based on these provisions, the claimants obtained an order to serve process against KCM as the necessary or proper party to the proceedings against Vedanta, the first defendant, which was domiciled in England. According to the practice direction, the court reserves discretion under the CPR 6.37(3) to deny permission to serve outside the jurisdiction unless it is satisfied that England

\footnotetext{
${ }^{11}$ Lungowe, para. 31. The primary way in which the case was put was in negligence: according to the claimants, Vedanta's duty of care arose as a result of its assumption of responsibility 'for ensuring that [KCM]'s mining operations do not cause harm to the environment or local communities, as evidenced by the very high level of control and direction that [Vedanta] exercise at all material times over the mining operations of [KCM] and its compliance with applicable health, safety and environmental standards'.

${ }^{12}$ Ibid., paras 31-8.

${ }^{13}$ Vedanta, para. 17.

${ }^{14}$ Jurisdiction against Vedanta derived from Art. 4(1) of Regulation (EU) No. 1215/2012 on Jurisdiction and the Recognition and Enforcement of Judgments in Civil and Commercial Matters [2012] OJ L351/1, according to which persons domiciled in an EU Member State shall be sued in the courts of that Member State. Notably, the UK left the EU on 31 January 2020, although the EU law will continue to apply until 31 December 2020.
} 
is the proper place for the trial. In order to properly exercise this discretion, the High Court addressed the following five questions: ${ }^{15}$

(a) Does the claimants' claim against KCM have a real prospect of success?

(b) If so, is there a real issue between the claimants and Vedanta?

(c) Is it reasonable for the court to try that issue?

(d) Is KCM a necessary or proper party to the claim against Vedanta?

(e) Is England the proper place in which to bring the claim?

After considering these questions, the High Court dismissed Vedanta's and KCM's applications against hearing the case in England by finding in favour of the claimants on the question of a real issue against the anchor defendant, Vedanta. ${ }^{16}$ Both the Court of Appeal ${ }^{17}$ and the Supreme Court ${ }^{18}$ upheld this decision.

\subsection{Vedanta's duty of care}

The Supreme Court's analysis included assessing whether Vedanta 'exercised a sufficiently high level of supervision and control of the activities at the mine, with sufficient knowledge of the propensity of those activities to cause toxic escapes into surrounding watercourses, as to incur a duty of care to the claimants'. ${ }^{19}$ Most importantly, the Court emphasized that establishing any relevant duty in a parent/subsidiary relationship 'depends on the extent to which, and the way in which, the parent availed itself of the opportunity to take over, intervene in, control, supervise or advise the management of the relevant operations (including land use) of the subsidiary'. ${ }^{20}$ In the present case, the Court concluded from the materials proffered by the claimants that Vedanta did in fact assert 'its responsibility for the establishment of appropriate group-wide environmental control and sustainability standards, for their implementation throughout the group by training, and for their monitoring and enforcement ${ }^{\prime}{ }^{21}$

\subsection{Access to justice}

Both the High Court and the Court of Appeal found that although Zambia was the proper place to bring the claim, 'there was a real risk that the claimants would not obtain substantial justice in the Zambian jurisdiction'. ${ }^{22}$ The Supreme Court, therefore, held that

\footnotetext{
${ }^{15}$ Lungowe, para. 97.

${ }^{16}$ Lungowe, para. 199.

${ }^{17}$ Lungowe and Others v. Vedanta Resources Plc and Another [2017] EWCA Civ 1528, para. 136.

18 Vedanta, paras 22 and 102.

19 Ibid., para. 55.

20 Ibid., para. 49.

${ }^{21} \mathrm{Ibid}$. While not a human rights case, the Supreme Court's articulation of Vedanta's duty of care towards the claimants is quite consistent with the UN Guiding Principles on Business and Human Rights, available at: https://www.ohchr.org/documents/publications/GuidingprinciplesBusinesshr eN.pdf, which call for corporate responsibility to respect human rights regardless of the business structure. See Principle 14.

22 Ibid. para. 22.
} 
Even if the court concludes [...] that a foreign jurisdiction is the proper place in which the case should be tried, the court may nonetheless permit (or refuse to set aside) service of English proceedings on the foreign defendant if satisfied, by cogent evidence, that there is a real risk that substantial justice will not be obtainable in that foreign jurisdiction. ${ }^{23}$

The Court further stated that the question of whether substantial justice is obtainable requires careful analysis of distinctive evidence. ${ }^{24}$ In this case, the Court considered the availability of resources, both financial and technical expertise, to effectively litigate a case of such complexity as the determining factor in assessing whether substantial justice was attainable for the claimants in the foreign jurisdiction. ${ }^{25}$ The evidence assessed by the court included cases concerning environmental damage and the testimony of the claimants and Zambian lawyers. ${ }^{26}$

On the question of funding, the High Court made the following finding that was deemed relevant by the Supreme Court:

The claimants have been described as being considerably below the average income earners in Zambia. Given that Zambia is one of the world's poorest countries, where the vast majority live at subsistence levels [...], the claimants would not be able to afford any legal representation. ${ }^{27}$

The court relied on the case Lubbe v. Cape plc, ${ }^{28}$ involving litigants from South Africa, in which the House of Lords found that the 'lack of the means, in South Africa, to prosecute [the] claims to a conclusion provides a compelling ground [...] for refusing to stay the proceedings' ${ }^{29}$ In Vedanta, the High Court compared the legal systems and economic situation in both South Africa and Zambia and concluded that there was compelling evidence that access to justice would be unavailable to the claimants who were worse off than their South African counterparts in Lubbe:

South Africa is the largest economy in southern Africa. It is a country where [Conditional Fee Agreements (CFAs)] are lawful. In addition, it has one of the most developed legal systems in the world. Yet despite all of that, the House of Lords concluded that the claimants would not obtain access to justice there. The general evidence in that case about South Africa contrasts starkly with the evidence here about Zambia, which is one of the world's poorest countries. CFAs are not lawful there. And on any view the legal system in Zambia is not well developed: indeed, in 2012 Zambia was the subject of a

\footnotetext{
23 Ibid., para. 89.

24 Ibid.

25 Ibid.

${ }^{26}$ See Lungowe, para. 184.

${ }^{27}$ Lungowe, para. 178.

${ }^{28}$ Lubbe and Ors v. Cape Plc [2000] UKHL 41 (concerning damages claims by over 3,000 South African residents and an English resident for personal injuries (and in some cases death) allegedly suffered as the result of exposure to asbestos and its related products in South Africa. The activities related to the production of asbestos were carried out by a South African subsidiary of the defendant, an English company named Cape, Plc.

${ }^{29}$ Ibid.
} 
report by the Bureau for Institutional Reform and Democracy which highlighted the dearth of lawyers in Zambia, and the consequences for its citizens. ${ }^{30}$

Based on the analysis of the decided cases and witness testimony, the High Court found that it was impossible for the claimants to obtain legal aid, that there was a dearth of lawyers in Chingola, the town where the alleged pollution occurred; furthermore, the lawyers lacked the relevant expertise to prosecute a case of this magnitude. ${ }^{31}$

Finally, the Supreme Court was persuaded that 'the track record in Zambia of litigation of this

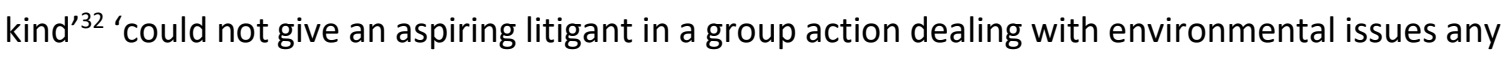
confidence that these cases would be appropriately managed and resolved'. ${ }^{33}$ The Supreme Court highlighted two decided cases, namely, Benson Shamilimo and 41 others v. Nitrogen Chemicals of Zambia Ltd ${ }^{34}$ and Nyasulu and 2,000 others v. KCM. ${ }^{35}$ In Shamilimo, concerning claims by a group of persons who were allegedly exposed to radiation, the claimants could not establish a causal link between 'their illnesses (which were proved) and the exposure to radiation (which was also proved)' ${ }^{36}$ The UK Supreme Court agreed with the finding of the High Court that the claimants failed to prove causation because they 'could not fund the necessary expert evidence to prove ${ }^{i t}{ }^{\prime}{ }^{37}$ In Nyasulu, a claim for damages arising from the discharge of effluent into the Mushishima Stream leading to pollution of the water source which feeds into the Kafue river, the claimants were awarded damages by the High Court. ${ }^{38}$ On the appeal to the Supreme Court of Zambia, the damages awarded to 1,989 claimants were set aside due to the lack of medical evidence to prove that the claimants had suffered any loss. ${ }^{39}$ The UK Supreme Court agreed with the High Court that 'there was in relation to both those cases evidence from which the judge was entitled to conclude that they supported rather than detracted from his overall finding that funding and local legal resources were insufficient to enable the claimants to obtain substantial justice in Zambia'. ${ }^{40}$

The decision in Vedanta thus expands the grounds that would limit claimants' capacity to obtain substantial justice, including the lack of technical expertise in addition to the lack of funding referred to in Lubbe. Notably, though, in both Lubbe and Vedanta the courts emphasized the need for evidence to demonstrate the unique circumstances of the particular cases in order to avoid creating a blanket precedent that lack of access to legal aid and financing would prevent claimants

\footnotetext{
${ }^{30}$ Lungowe, paras 175-176.

${ }^{31}$ Lungowe, para. 186. The dearth of lawyers was proved using a 2012 report on access to justice in Zambia by the Bureau for Institutional Reform and Democracy which highlighted the dearth of lawyers in Zambia, and the consequences for its citizens with only four lawyers in Chingola town.

32 Ibid., para. 190.

33 Ibid., para. 194.

${ }^{34}$ 2007/HP/0725.

35 2007/HP/1286.

${ }^{36}$ Lungowe, para. 191.

${ }^{37}$ Vedanda, p. 37.

${ }^{38}$ Lungowe, para. 191.

39 Ibid.

${ }^{40}$ Ibid., p. 37.
} 
from obtaining access to justice in a foreign jurisdiction. The court applied the test of appropriate forum stated in the case of Spiliada Maritime Corporation v. Cansulex Ltd. ${ }^{41}$

\section{The transnational significance of the decision}

The decision in Vedanta is an important precedent for providing access to justice for foreign claimants in transnational corporate liability litigation. ${ }^{42}$ Given the global presence of English companies, and the fact that their foreign subsidiaries have been involved in multiple cases of environmental damage in the host states, ${ }^{43}$ including large-scale disasters such as the Mariana dam disaster in Brazil, ${ }^{44}$ Vedanta could give an impetus to future claims brought in the English courts. The litigation following the Mariana dam disaster is one of the most recent examples of an instance where this could happen, as the disaster resulted not only in proceedings against the subsidiary and both its parents in Brazil, but also proceedings in Australia, where shareholders filed a lawsuit against BHP Billiton, claiming that the company knew about the safety risks prior to the disaster but failed to take any action to prevent it, and in England, where more than 240,000 claimants, including Brazilian municipalities and indigenous communities, filed a lawsuit against BHP Billiton seeking compensation for damages caused by the dam collapse. ${ }^{45}$

\subsection{Suing parent companies in their home state}

Depending on the circumstances, suing parent companies in their home states for the activities of their foreign subsidiaries may be advantageous or even vital to the claimants' success. For

\footnotetext{
${ }^{41}$ Spiliada Maritime Corporation v. Cansulex Ltd [1987] A.C. 460. The basic principle is that a stay will only be granted on the ground of forum non conveniens where the court is satisfied that some other available forum, having competent jurisdiction, is the appropriate forum for the trial of the action, where the case may be tried more suitably in the interest of all the parties and for the ends of justice (Spiliada, p. 476).

${ }^{42}$ It is beyond the scope of this article to discuss cases where the parent company itself was involved in the polluting activities abroad, or cases where the harm was caused by a subsidiary of an English company in England.

${ }^{43}$ E.g., Vedanta has subsidiaries not only in Zambia, but also in several other countries (details available at: https://www.vedantaresources.com/Pages/Home.aspx), including India and Ireland, where the mining operations of these subsidiaries caused air and groundwater pollution as well as damage to farmlands, resulting in litigation before national courts. See: Dunne v. Vedanta Lisheen Mining Limited [2016] IEHC 500, High Court of Ireland; The State of Tamil Nadu and Others v. Vedanta Limited [2019] No. 23/2019, Supreme Court of India.

${ }^{44}$ The 2015 Mariana dam disaster is considered to be the worst environmental disaster in Brazil's history, with toxic waste from the collapsed mine devastating the local river and reaching the Atlantic Ocean as well as dealing irreversible damage to local animal and plant life and killing 19 people. The owner of the dam, Samarco Mineração S.A., is a joint venture of BHP, an Anglo-Australian mining, metals and petroleum company, and Vale S.A., a Brazilian metals and mining company. See B. Tuncak, 'Lessons from the Samarco Disaster' (2017) 2(1) Business and Human Rights Journal, pp. 157-62. Notably, in January 2019, Vale S.A. was involved in yet another catastrophic failure in one of its mines - the Brumadinho dam disaster - that left more than 200 people dead and local rivers and soil substantially polluted.

${ }^{45}$ See Business and Human Rights Resource Centre, 'BHP Billiton \& Vale lawsuit (re dam collapse in Brazil)', available at https://www.business-humanrights.org/en/bhp-billiton-vale-lawsuit-re-dam-collapse-inbrazil.
} 
example, the parent company may have the financial resources that are unavailable to the subsidiary to satisfy the claim. Thus, one of the concerns in Vedanta was that KCM would not have sufficient funds to cover the damages due to its uncertain financial position, with the High Court concluding that 'there is a real risk that, without Vedanta's support, [KCM] may have insufficient resources to meet the claims' ${ }^{46}$ Other financial considerations, such as the cost of litigation, and more favourable civil procedural arrangements can also render the home country a more attractive forum for litigation. These considerations can be decisive in determining that the claimants would not obtain substantial access to justice in the host state's courts, as seen in Vedanta as well as other environmental cases, including the abovementioned Lubbe and Connelly v. RTZ PIc. ${ }^{47}$

Similarly, the lack of legal expertise in the host state - as in Vedanta - can also be a decisive factor. In Zambia, this lack of expertise is also observable among trial courts, as demonstrated by Martha Mutizhe Kangwa \& 27 others v. Zambia Environmental Management Agency \& 2 others. ${ }^{48}$ The claimants contended that the construction of a cement factory would negatively affect the neighbouring farms by relying on expert testimony from a hydrologist, a mining engineer and a veterinary surgeon. ${ }^{49}$ The trial court rejected the testimony and dismissed the claim as it considered that these experts 'were not experts in environmental issues, but experts in segments like mining, water, veterinary'..$^{50}$ On the appeal, the Supreme Court held that the trial court misunderstood environmental issues in dismissing the testimony, as all these segments were facets of the environment as defined by the repealed Environmental Protection and Pollution control Act pursuant to which the claim was brought. ${ }^{51}$ Still, the Supreme Court held that the trial court was entitled to accept or decline the expert testimony based on the established principles of law of evidence regarding the weight that a court could attach to evidence. ${ }^{52}$

Meanwhile, yet another critical reason for pursuing litigation abroad is ineffective enforcement in the subsidiary's host state. The latter scenario is a persistent and acute problem in many

\footnotetext{
${ }^{46}$ Lungowe, paras 21-24, 80-82.

47 Connelly v. RTZ Plc. [1998] AC 854. In Connelly, the claimant was a UK citizen who allegedly developed cancer while working in a uranium mine in Namibia operated by a South African company that was a subsidiary of an English company RTZ Plc. The claimant sued the parent company, alleging that it was negligent in the implementation of the policy and supervision of health, safety and environmental protection at the mine.

48 2008/HP/245 (Kangwa).

${ }^{49}$ Kangwa, at J12.

50 Ibid., at J49.

${ }^{51}$ Martha Mutizhe Kangwa \& 27 Others v. Zambia Environmental Management Agency \& 2 Others SCZ, SCZ/8//287/2011 Judgment No. 49 of 2014.

52 Ibid.
} 
developing countries, ${ }^{53}$ as illustrated by Gbemre v. Shell Nigeria. ${ }^{54}$ Gbemre was remarkable in several ways, most notably because, among other things, it was the very first case raising the issue of climate change in an African court. The claimant alleged that the oil production activities (gas flaring) of the defendants, Shell Petroleum Development Company of Nigeria Ltd. (SPDC) and the Nigerian National Petroleum Corporation, adversely affected his life and health as well as the local environment thus violating his rights to life and dignity, enshrined in the Nigerian Constitution and the African Charter on Human and Peoples' Rights. ${ }^{55}$ The Federal High Court of Nigeria was persuaded by the claimant's arguments. ${ }^{56} \mathrm{However}$, the decision was never enforced and did not halt the practice of gas flaring in Nigeria. ${ }^{57}$

Understandably, home state courts dealing with transnational cases where the host state's legal system allegedly suffers from a lack of expertise or effective enforcement will exercise particular caution in order to avoid raising 'serious issues of comity and exorbitant jurisdiction' ${ }^{58}$ and thus refuse to hear such claims. However, the abovementioned scenarios also demonstrate that victims of corporate abuse, particularly those from developing countries, may face a poor choice between having their case against both the parent and the subsidiary companies heard in the home state's courts or, possibly, not having it heard at all. ${ }^{59}$

\footnotetext{
${ }^{53}$ It has been observed that even if victims of environmental damage and human rights abuses succeed in their cases brought before African national courts or regional international bodies, the failure of many African governments to enforce these decisions significantly impedes access to justice. See, e.g., L. Chenwi, 'The Right to a Satisfactory, Healthy, and Sustainable Environment in the African Regional Human Rights System', in J.H. Knox \& R. Pejan (eds), The Human Right to a Healthy Environment (Cambridge University Press, 2018), pp. 59-85; see also the chapters 37,42 and 43 discussing the particular vulnerability of communities in Africa to environmental and human rights abuses in J.R. May \& E. Daly (eds), Human Rights and the Environment: Legality, Indivisibility, Dignity and Geography (Edward Elgar, 2019).

${ }^{54}$ Jonah Gbemre v. Shell Petroleum Development Corporation of Nigeria Ltd and Ors, (2005), Federal High Court, Suit No: FHC/B/CS/53/05.

${ }^{55}$ Gbemre, p. 1. See African Charter on Human and Peoples' Rights, Banjul, 19 January 1982, OAU Doc $\mathrm{CAB} / \mathrm{LEG} / 67 / 3$ rev 5 .

${ }^{56}$ Gbemre, pp. 30-1.

${ }^{57}$ See B. Faturoti, G. Agbaitoro \& O. Onya, 'Environmental Protection in the Nigerian Oil and Gas Industry and Jonah Gbemre v. Shell PDC Nigeria Limited: Let the Plunder Continue?' (2019) 27(2) African Journal of International and Comparative Law, pp. 225-45, at 235-6; E. Ukala, 'Gas flaring in Nigeria's Niger Delta: Failed Promises and Reviving Community Voices' (2010) 2(1) Washington and Lee Journal of Energy, Climate, and the Environment, pp. 97-126.

${ }^{58}$ E.M. Blanco \& B. Pontin, 'Litigating Extraterritorial Nuisances under English Common Law and UK Statute' (2017) 6(2) Transnational Environmental Law, pp. 285-308, at 305. See also the UK Supreme Court in Vedanta, para. 11, noting that 'a conclusion that a foreign jurisdiction would not provide substantial justice risks offending international comity.'

${ }^{59}$ See, e.g., C.A. Whytock \& C. Burke Robertson, 'Forum Non Conveniens and the Enforcement of Foreign Judgments' (2011) 111(7) Columbia Law Review, pp. 1444-1521, discussing how different standards in the application of the forum non conveniens doctrine can create a transnational access to justice gap; see also M. Gardner, 'Retiring Forum Non Conveniens' (2017) 92(2) New York University Law Review, pp. 390-461.
} 


\subsection{Transnational corporate liability for environmental damage}

In today's globalized world, multinational corporations (MNCs) have become 'both legally ubiquitous and yet legally invisible ${ }^{60}$ due to their presence in multiple jurisdictions and legal separation between the parent companies and the subsidiaries. ${ }^{61}$ At the time of writing, numbers of such corporations and their subsidiaries are reaching into the six digits and seven digits, respectively. ${ }^{62}$ The subsidiaries often operate and cause harm in developing countries with a weaker rule of law, ${ }^{63}$ where vulnerable populations risk becoming hostages of MNCs' business deals with local governments. ${ }^{64}$ Vulnerable groups are further hampered by rules such as forum non conveniens and arrangements such as the corporate veil, which play into the hands of MNCs. ${ }^{65}$ These situations can lead to severe social and environmental justice problems ${ }^{66}$ and even human rights violations. ${ }^{67}$ In the absence of international law provisions addressing extraterritorial abuses by $\mathrm{MNCs}^{68}{ }^{6}$ and the near-universal absence of such legislation at the

${ }^{60}$ V. Grosswald Curran, 'Harmonizing Multinational Parent Company Liability for Foreign Subsidiary Human Rights Violations' (2016) 17(2) Chicago Journal of International Law, pp. 403-446, at 406.

61 Ibid., p. 408.

${ }^{62}$ G.L. Skinner, 'Beyond Kiobel: Providing Access to Judicial Remedies for Violations of International Human Rights Norms by Transnational Business in a New (Post-Kiobel) World' (2014) 46(1) Columbia Human Rights Law Review, pp. 158-265, at 168.

${ }^{63} \mathrm{See}$, for example, the discussion on the large-scale environmental degradation, including air, water and land pollution, in Nigeria, caused by oil exploration, in H.P. Faga \& U. Uchechukwu, 'Oil Exploration, Environmental Degradation, and Future Generations in the Niger Delta: Options for Enforcement of Intergenerational Rights and Sustainable Development Through Legal and Judicial Activism' (2019) 34 Journal of Environmental Law and Litigation, pp. 185-218, at 194-204. See, also, the discussion on the role of MNCs in dumping of toxic waste in African countries in M.V.S. Sirleaf, 'Prosecuting Dirty Dumping in Africa', in C.C. Jalloh, K.M. Clarke \& V.O. Nmehielle (eds), The African Court of Justice and Human and Peoples' Rights in Context: Development and Challenges (Cambridge University Press, 2019), pp. 553-589.

${ }^{64}$ R. Bratspies, 'Corrupt at Its Core: How Law Failed the Victims of Waste Dumping in Cote d'Ivoire' (2018) 43(2) Columbia Journal of Environmental Law, pp. 417-473 (discussing the large-scale illegal resource extraction in Africa, Asia, Latin America and Russia as well as the multiple incidents of violations of law before, during and after the dumping of particularly hazardous waste in Cote d'Ivoire by different parties involved).

${ }^{65}$ For a discussion on how these doctrines benefit MNCs see, for example, J.A. Kirshner, 'Why is the US Abdicating the Policing of Multinational Corporations to Europe: Extraterritoriality, Sovereignty, and the Alien Tort Statute' (2012) 30(2) Berkeley Journal of International Law, pp. 259-302, at 264-265; A. Yilmaz Vastardis \& R. Chambers, 'Overcoming the Corporate Veil Challenge: Could Investment Law Inspire the Proposed Business and Human Rights Treaty?' (2018) 67(2) International \& Comparative Law Quarterly, pp. 389-423.

${ }^{66}$ H.M. Osofsky, 'Climate Change and Environmental Justice: Reflections on Litigation over Oil Extraction and Rights Violations in Nigeria' (2010) 1(2) Journal of Human Rights and the Environment, pp. 189-210, at 192.

67 See, for example, I.I. Onwuazombe, 'Human Rights Abuse and Violations in Nigeria: A Case Study of the Oil-Producing Communities in the Niger Delta Region' (2017) 22(1) Annual Survey of International and Comparative Law, pp. 115-160, at 118; A. Grear \& B.H. Weston, 'The Betrayal of Human Rights and the Urgency of Universal Corporate Accountability: Reflections on a Post-Kiobel Lawscape' (2015) 15(1) Human Rights Law Review, pp. 21-44, at 40, observing that 'human rights are inadequately protected in the face of TNC complexity, power and global influence' and that 'the various legal strategies deployed to protect human rights by recruiting alternative legal avenues and forms of accountability are ultimately unsatisfying'.

68 R.V. Percival, 'Global Law and the Environment' (2011) 86(3) Washington Law Review, pp. 579-634, at 601-602; A. Grear, 'Corporations, Human Rights, and the Age of Globalization: Another Look at the "Dark 
national level, ${ }^{69}$ the decisions of home state courts on the liability of parent companies for the harms caused by their foreign subsidiaries are vital. At the same time, such cases are highly factspecific. $^{70}$

Thus, in contrast to Vedanta, the English courts dismissed Okpabi v. Shell, ${ }^{71}$ a case concerning oil pollution in Nigeria that has affected wide areas of land across the Niger Delta and local waterways, disrupting the lives of a considerable number of people. The claimants - about 42,500 Nigerian citizens - sued Royal Dutch Shell plc (RDS), an Anglo-Dutch company, and its local subsidiary SPDC, responsible for onshore oil operations in Nigeria, in the English courts. ${ }^{72}$ The claimants sought damages arising from 'serious and ongoing pollution and environmental damage caused by oil spills emanating from the defendants' oil pipelines and associated infrastructure. ${ }^{73}$ The High Court ruled that the claims could not proceed in the English courts because there was no justiciable issue against the parent company as its control over the subsidiary's activities was insufficient to establish a duty of care vis-à-vis the claimants. ${ }^{74}$ On appeal, Lord Justice Sales was of opinion that the claimants '[had] shown at this stage that they have a good arguable case that RDS owed them a duty of care at the material times and that it breached that duty of care, resulting in losses to the claimants of a kind in respect of which damages are recoverable'.$^{75}$ The Court of Appeal majority, though, upheld the decision of the High Court. ${ }^{76}$ The majority's decision, however, is open to criticism for taking 'a highly restrictive

Side" in the Twenty-First Century', in B.H. Weston \& A. Grear (eds) Human Rights in the World Community: Issues and Action (University of Pennsylvania Press, 2016), pp. 416- 426, at 418-421; P. Muchlinski, 'The Development of Human Rights Responsibilities for Multinational Enterprises', in R. Sullivan \& M. Robinson (eds), Business and Human Rights: Dilemmas and Solutions (Routledge, 2017), pp. 33-51, at 38-39.

69 See D. Palombo, 'The Duty of Care of the Parent Company: A Comparison between French Law, UK Precedents and the Swiss Proposals' (2019) 4(2) Business and Human Rights Journal, pp. 265-286, at 275: At political level, attempts to introduce corporate duty of vigilance legislation in several countries have consistently faced opposition, alleging that such legislation would put national businesses in a disadvantaged position comparing to foreign companies due to potential exposure to liability litigation. The notable exception to this is France, which in 2017 became the first country to pass legislation establishing 'a due diligence obligation for French parent companies to monitor the extraterritorial human rights and environmental abuses committed by their offshore affiliates'. See also Curran, n. 60 above, at 415-422.

70 J.F. Sherman, 'Should a Parent Company Take a Hands-off Approach to the Human Rights Risks of its Subsidiaries?' (2018) 19(1) Business Law International, pp. 23-36, at 28.

${ }^{71}$ Okpabi and Others v. Royal Dutch Shell Plc and Another [2017] EWHC 89 (TCC), 26 January 2017 (Okpabi, 2017); Okpabi and others v. Royal Dutch Shell Plc and Shell Petroleum Development Company of Nigeria Ltd [2018] EWCA Civ 191 (Okpabi, 2018).

72 Another case that arose under very similar circumstances is The Bodo Community and others v. Shell Petroleum Development Company of Nigeria Ltd [2014] EWHC 1973 (TCC). In that case, however, the claims proceeded against the subsidiary on the sole basis of an agreement that it would voluntarily submit to the jurisdiction and admit responsibility for the pollution.

73 Okpabi, 2018, para. 1.

${ }^{74}$ Okpabi, 2017, paras 113-116, 119.

75 Okpabi 2018, para. 134.

${ }^{76}$ A similar conclusion was reached in a non-environmental case AAA v. Unilever PIc [2017] EWHC 371 (QB). The case was brought by victims of ethnic violence in Kenya following the general elections, when groups of attackers invaded the tea plantation operated by the Kenyan subsidiary of an English-based company, killing, raping and physically assaulting the workers. The Court of Appeal dismissed the claim against the parent company thus preventing the claimants from asserting jurisdiction against the subsidiary company in England. 
approach for the imposition of the duty of care on English-domiciled parent companies in relation to the overseas activities of their subsidiaries' as well as for imposing 'an unreasonably high burden on the claimants to establish an arguable case on the duty of care at the jurisdictional stage of proceedings'. ${ }^{77}$ As of March 2020, the case was pending in the Supreme Court.

So far, however, none of the English cases involving a parent company's duty of care have been decided on the merits. Nonetheless, Vedanta confirmed that English parent companies could owe a duty of care to foreign claimants affected by operations of their subsidiaries in the host states and that the English courts could have jurisdiction to hear such cases even when a foreign court is seemingly a more appropriate place for the trial. This development also reflects a growing trend of home state courts agreeing to hear claims against the parent companies and their foreign subsidiaries and, even more importantly, holding the parent companies liable in some of these cases. ${ }^{78}$ The most notable example of this trend is Akpan v. Shell where the Dutch courts held that they had jurisdiction over the claims brought by Nigerian citizens against the RDS and SPDC for oil spills from an oil well operated by the latter. ${ }^{79}$ Overall, this might well be considered part of a broader global trend towards corporate liability for various harms, including human rights violations. ${ }^{80}$

At the same time, this trend contrasts with the developments in the United States (US), which may seem a particularly lucrative jurisdiction when it comes to transnational liability claims against corporations.$^{81}$ The US is home state to a vast number of the world's largest MNCs, its legal system allows the pursuit of different avenues of claims in federal or state courts, ${ }^{82}$ while the Alien Tort Statute (ATS), ${ }^{83}$ a provision unique to the US which explicitly grants US courts jurisdiction to hear civil cases brought by non-US nationals for torts committed in violation of

\footnotetext{
${ }^{77}$ E. Aristova, 'Tort Litigation against Transnational Corporations in the English Courts: The Challenge of Jurisdiction' (2018) 14(2) Utrecht Law Review, pp. 6-21, at 16.

${ }^{78}$ See the discussion on the relevant case law in Curran, n. 60 above, at 434-444.

${ }^{79}$ Akpan v. Royal Dutch Shell PLC, ECLI: NL: RBSGR: 2013: BY9854 (District Court the Hague, 2013,); Dooh v. Royal Dutch Shell PLC, ECL-NL: GHDHA: 2015:3586 (Court of Appeal the Hague, 17 December 2015,). Notably, in its ruling, the Dutch courts made multiple references to the English case-law. For a broader discussion on this case see N. Jägers, K. Jesse \& J. Verschuuren, 'The Future of Corporate Liability for Extra territorial Human Rights Abuses: The Dutch Case Against Shell' (2013) 107 AIIL Unbound, pp. e36-e41; M. Weller \& A. Pato, 'Local Parents as 'Anchor Defendants' in European Courts for Claims against their Foreign Subsidiaries in Human Rights and Environmental Damages Litigation: Recent Case Law and Legislative Trends' (2018) 23(2) Uniform Law Review, pp. 397-417.

${ }^{80} \mathrm{See}$, for example, the recent decision of the Supreme Court of Canada in non-environmental case Nevsun Resources Ltd v. Araya, 2020 SCC 5, concerning Eritrean workers' forced labour in a mine owned by a Canadian company and confirming that corporations are not immune from direct liability for human rights violations under customary international law: 'it is not "plain and obvious" that corporations today enjoy a blanket exclusion under customary international law from direct liability for violations of "obligatory, definable, and universal norms of international law", or indirect liability for their involvement in [...] "complicity offenses"' (para. 113).

${ }^{81}$ See C.A. Whytock, 'The Evolving Forum Shopping System' (2011) 96(3) Cornell Law Review, pp. 481-534, at 490-497 (discussing the advantages that foreign claimants could traditionally enjoy by perusing transnational litigation in US courts).

${ }^{82}$ See, for example, S. Baughen, Human Rights and Corporate Wrongs: Closing the Governance Gap (Edward Elgar Publishing, 2015), pp. 54-59, 78-80, 152-171.

${ }^{83} 28$ U.S.C. § 1350.
} 
customary international law or treaties ratified by the US, ${ }^{84}$ appears to fill an extremely important and broad legislative gap.

These lucrative possibilities, however, very rarely materialize in reality. The application of ATS has been subject to restrictive interpretation by the US Supreme Court, limiting the jurisdiction of the US courts when dealing with transnational claims brought under this act. In Kiobel v. Shell, which concerns widespread human rights violations carried out by the Nigerian military and supported by Shell against Ogoni people who were protesting against environmental pollution caused by $\mathrm{SPDC}^{85}$ the US Supreme Court ruled that the claim did not 'touch and concern the territory of the [US] with sufficient force' and 'mere corporate presence' of the company in the US was insufficient to establish jurisdiction. ${ }^{86}$

The US Supreme Court placed an even greater restriction to the application of the ATS to claims against foreign entities in a recent non-environmental case, Jesner v. Arab Bank, ${ }^{87}$ which expressly excludes foreign companies from ATS liability on political grounds. ${ }^{88}$ The Court did not address the question whether this exclusion also applies to US companies, ${ }^{89}$ which is highly relevant with

84 See S.P. Mulligan, The Alien Tort Statute (ATS): A Primer (1 June 2018), available at https://crsreports.congress.gov/product/pdf/R/R44947/4, at 1. Notably, while the US Supreme Court held that 'the ATS is a jurisdictional statute creating no new causes of action', it considered that in certain narrow circumstances courts may recognize a common law cause of action for claims based on contemporary international law. See Sosa v. Alvarez-Machain, 542 U.S. 692, 724-725 (2004).

${ }^{85}$ Kiobel v. Royal Dutch Petroleum, 569 US 108 (2013). Directly related to these circumstances was Wiwa v. Royal Dutch Petroleum Co. 226 F 3d 88 (2d Cir 2000), brought by the family of the executed Ogoni activist Ken Saro-Wiwa under ATS against RDS and SPDC. In 2009, RDS agreed to pay $\$ 15.5$ million to settle the case. Similar circumstances occurred in Bowoto v. Chevron Corp. 621 F.3d 1116 ( $9^{\text {th }}$ Cir. 2010), which was also brought under the ATS and dismissed by the US Court of Appeals for the Ninth Circuit. In Bowoto, a group of Nigerian citizens protesting against the environmental damage caused by Chevron Nigeria Ltd, a subsidiary of the US-based oil company Chevron, were attacked by Nigerian military, allegedly hired by Chevron to suppress the protests. The claimants did not pursue claims against the subsidiary company.

${ }^{86} \mathrm{Kiobel}$, at 125 . It has been observed that this formulation left more questions than answers and led to conflicting interpretations by the lower courts. See, for example, R.P. Alford, 'The Future of Human Rights Litigation After Kiobel' (2014) 89(4) Notre Dame Law Review, pp. 1749-1772, at 1754 (referring to the decision as 'complex and confusing, offering scant guidance as to how lower courts should proceed when claims touch and concern U.S. territory'); For a discussion of different interpretations see: Note, 'Clarifying Kiobel's Touch and Concern Test' (2017) 130(7) Harvard Law Review, pp. 1902-1923. This decision did not put an end to the claimants' attempts to hold Shell accountable, as they have subsequently pursued litigation in the Netherlands, where it may have better prospects of success - see Claimants v. Royal Dutch Shell Plc and others, ECLI:NL:RBDHA:2019:6670 (the Hague District Court, 2019), holding that Dutch courts have jurisdiction to hear the claims (paras 4.23-4.29).

87 Jesner v. Arab Bank, PLC 138 S. Ct. 1386 (2018). The lawsuit was brought by non-US victims of terrorist attacks in Israel, the West Bank and Gaza and their families, alleging that Arab Bank aided and abetted the terrorist groups in the Middle East by transferring funds to their accounts, including transactions passing through the bank's offices in New York City.

88 The court held that 'any imposition of corporate liability on foreign corporations for violations of international law must be determined in the first instance by the political branches of the Government' (at 1408).

89 Instead, the US Supreme Court made the following observation: 'Because this case involves a foreign corporation, we have no need to reach the question whether an alien may sue a United States corporation under the ATS. And since such a suit may generally be brought in federal court based on diversity 
regard to certain types of extraterritorial environmental harms caused by US companies on US soil - most notably, contribution to climate change. ${ }^{90}$ However, in terms of the foreign subsidiaries of US companies, Jesner seems to foreclose the possibility of suit under the ATS, unless the claimants convince the courts that the parent companies are directly liable for the conduct of the subsidiaries. ${ }^{91}$ Still, even in the latter scenario, claimants would likely find it difficult to succeed due to the reluctance of the US courts to pierce the corporate veil. ${ }^{92}$

A restrictive approach of the US courts to extraterritorial claims is observable in non-ATS cases as well, where the courts can refuse to exercise jurisdiction over claims related to the responsibility of the US transnational companies for their activities abroad on various grounds. ${ }^{93} \mathrm{~A}$ notable example of this trend are two high-profile environmental cases concerning large-scale pollution originating from subsidiaries of US-based companies in India ${ }^{94}$ and Ecuador and Peru, ${ }^{95}$ respectively, dismissed by the US courts on forum non conveniens grounds despite compelling evidence that courts in these countries were not adequately prepared to process these cases. ${ }^{96}$ In dismissing the abovementioned cases on procedural grounds, the US courts seemed to adhere more to political reasons ${ }^{97}$ than to considerations of justice. While these developments do not necessarily mean that transnational environmental and human rights claims in the US have reached a dead end, ${ }^{98}$ they may indeed render the English, the Dutch and other nations' courts,

jurisdiction, 28 U.S.C.§ 1332(a)(2), it is unclear why ATS jurisdiction would be needed in that situation'. Jesner, at 1410 (note*).

${ }^{90}$ M. Dellinger, 'Post-Jesner Climate Change Lawsuits Under the Alien Tort Statute' (2019) 44(S) Columbia Journal of Environmental Law, pp. 241-297, at 269. For a discussion on the prospective transnational climate change liability claims brought by foreign claimants directly against the US private emitters in the US courts or in their home state courts see M. Byers, K. Franks \& A. Gage, 'The Internationalization of Climate Damages Litigation' (2017) 7(2) Washington Journal of Environmental Law \& Policy, pp. 264-319. Corporate climate change liability will be discussed in more detail in the next part of this article.

${ }^{91}$ W.S. Dodge, 'Corporate Liability Under the US Alien Tort Statute: A Comment on Jesner v. Arab Bank' (2019) 4(1) Business and Human Rights Journal, pp. 131-137, at 135.

$92 \mathrm{lbid}$.

${ }^{93}$ For example, political question, sovereign immunity, comity, forum non conveniens, etc. Baughen, at 5980. See also P.K. Bookman, 'Litigation Isolationism' (2015) 67(5) Stanford Law Review, pp. 1081-1144.

${ }_{94}$ In re Union Carbide Corp. Gas Plant Disaster at Bhopal, India in Dec., 1984, 809 F.2d 195 (2d Cir. 1987). For a discussion of this case see U. Baxi, 'Writing about Impunity and Environment: The Silver Jubilee' of the

Bhopal Catastrophe' (2010) 1(1) Journal of Human Rights and the Environment, pp. 23-44.

${ }^{95}$ Aguinda v. Texaco, Inc., 303 F.3d 470 (2d Cir. 2002). For a discussion of this case see Yilmaz Vastardis and Chambers, n. 65 above, at 407-411.

${ }^{96}$ See H. van Loon, 'Principles and Building Blocks for a Global Legal Framework for Transnational Civil Litigation in Environmental Matters' (2018) 23(2) Uniform Law Review, pp. 298-318, at 309; See also C. Liu, 'Escaping Liability via Forum Non Conveniens: ConocoPhillips's Oil Spill in China' (2014) 17(2) University of Pennsylvania Journal of Law and Social Change, pp. 137-174.

${ }^{97}$ See, for example, W.W. Heiser, 'Forum Non Conveniens and Choice of Law: The Impact of Applying Foreign Law in Transnational Tort Actions' (2005) 51(3) Wayne Law Review, pp. 1161-1192, at 1170; E.A. Posner \& C.R. Sunstein, 'Chevronizing Foreign Relations Law' (2007) 116(6) Yale Law Journal, pp. 1170-1229; W.S. Dodge, 'International Comity in American Law' (2015) 115(8) Columbia Law Review, pp. 2071-2142.

${ }^{98}$ See Grear \& Weston, n. 67 above, at 37, arguing that the outcome in Kiobel 'strengthens the rationales for paying attention to non-[ATS] strategies'. An example of a more successful outcome in non-ATS transnational environmental litigation is Jam et al. v. International Finance Corp. 139 S.Ct. 759 (2019), recently addressed by the US Supreme Court, where a group of farmers and fishermen from India sued the 
which have demonstrated their willingness to hear such claims, a more attractive forum for transnational litigation against MNCs in the long term. ${ }^{99}$

\section{Implications for potential climate change liability claims}

Apart from claims concerning corporate liability for conventional environmental damage, Vedanta is also potentially relevant for prospective claims against English mining, fossil fuel producing companies and other companies and their foreign subsidiaries for their contribution to global greenhouse gas (GHG) emissions and, consequently, climate change. In Okpabi, the Court of Appeals referred to the duty to 'reduce global warming' as an 'abstract [...] concep[t] of moral responsibility' as distinguishable from a 'duty owed to a particular person or class of persons. ${ }^{100}$ Such a definition, however, appears to ignore the fact that the government's duty to address climate change, has already been recognized by a number of foreign courts, including by the US Supreme Court, ${ }^{101}$ the Supreme Court of Colombia, ${ }^{102}$ the Supreme Court of the Netherlands, ${ }^{103}$ and lower courts in other countries around the world. ${ }^{104}$ Notably, a governmental duty of care with regard to climate change is fairly obvious as the cause of action stems from both national and international law requirements for states to address climate change. ${ }^{105}$ Similar developments

International Finance Corporation (IFC) for inadequate supervision of the construction of a coal-fired power plant in the state of Gujarat, India. The IFC maintained that it was immune from suit under the 1945 International Organizations Immunities Act and moved to dismiss for lack of jurisdiction. The US Supreme Court held that the Act does not grant absolute immunity from suit to international organizations. Notably, though, in Jam the defendant was not a private company but an international organization with 184 member countries, including the US and India.

${ }^{99}$ See, for example, Bookman, n. 93 above, at 1116 (noting that the US 'is no longer presumptively plaintiffs' favorite forum' and that 'securities, environmental, and human rights litigation provide examples of types of litigation that are gradually migrating abroad').

100 Okpabi 2018, para. 88.

101 Massachusetts v. EPA 549 U.S. 497 (2007). The Supreme Court held that the US Environmental Protection Agency abdicated its responsibility under the federal air quality legislation to regulate automobile GHG emissions.

102 Future Generations v. Ministry of the Environment, STC4360 (2018). The claimants successfully challenged the Colombian government's inaction with regard to deforestation in the Amazon region, that, according to the claimants, greatly contributed to the total volume of GHG emissions in the country and therefore, climate change.

103 The State of the Netherlands v. Urgenda Foundation, ECLI:NL:HR:2019:2007 (2019). The court held that the state was breaching its duty of care by failing to pursue more ambitious GHG reduction targets. See J. van Zeben, 'Establishing a Governmental Duty of Care for Climate Change Mitigation: Will Urgenda Turn the Tide?' (2015) 4(2) Transnational Environmental Law, pp. 339-57; and B. Mayer, The State of the Netherlands v. Urgenda Foundation: Ruling of the Court of Appeal of The Hague (9 October 2018) (2019) 8(1) Transnational Environmental Law, pp. 167-92.

104 See S. Varvastian, 'The Human Right to a Clean and Healthy Environment in Climate Change Litigation' (2019) 2019(09) Max Planck Institute for Comparative Public Law \& International Law (MPIL) Research Paper, pp. 1-18.

105 See, e.g., A.-J. Saiger, 'Domestic Courts and the Paris Agreement's Climate Goals: The Need for a Comparative Approach' (2020) 9(1) Transnational Environmental Law, pp. 37-54. 
are potentially possible in case of private emitters, ${ }^{106}$ although determining the scope of their liability may be more difficult.

For instance, in the US case American Electric Power Co. v. Connecticut ${ }^{107}$ brought by a group of states against several electric power corporations that owned and operated fossil fuel-fired powerplants across the US, the Supreme Court held that the federal Clean Air Act, granting the US Environmental Protection Agency the power to set emission standards (following the Supreme Court's decision in Massachusetts), displaces federal common law nuisance claims for domestic GHG emissions. In another US case Native Village of Kivalina v. ExxonMobil Corp. ${ }^{108}$ where an Inupiat Eskimo village of Kivalina in Alaska sought to recover money damages related to its forced relocation due to the erosion of sea ice around the village from a group of the world's largest fossil fuel producers, the Ninth Circuit expanded this displacement rule to cover claims for damages based on oil producers' past emissions. Nonetheless, the outcome in these early US cases is not necessarily indicative of impending developments both in the US and elsewhere, and some examples below suggest that such claims could potentially go beyond the procedural stage, with the decision in Vedanta opening some interesting new perspectives.

First and foremost, a likely catalyst for a surge in climate change liability claims against private emitters are the recent studies tracing GHG emissions to corporate entities producing fossil fuels, including several English MNCs. ${ }^{109}$ Hence, following two early high-profile cases against BP (one of the largest corporate contributors to global carbon dioxide emissions since the Industrial Revolution) in the US, ${ }^{110}$ in recent years the company has faced a cascade of lawsuits brought by US cities and municipalities seeking compensation for climate change adaptation measures in the US courts, relying on the abovementioned GHG emissions tracing studies. ${ }^{111}$ Notably, these

\footnotetext{
106 See G. Ganguly, J. Setzer \& V. Heyvaert, 'If at first You Don't Succeed: Suing Corporations for Climate Change' (2018) 38(4) Oxford Journal of Legal Studies, pp: 841-868.

${ }^{107}$ American Electric Power Co. v. Connecticut, 564 U.S. 410, 429 (2011).

108 Native Village of Kivalina v. ExxonMobil Corp., 696 F.3d 849, 856-858 (9 ${ }^{\text {th }}$ Cir. 2012).

${ }^{109}$ See: R. Heede, 'Tracing Anthropogenic Carbon Dioxide and Methane Emissions to Fossil Fuel and Cement Producers, 1854-2010' (2014) 122(1-2) Climatic Change, pp: 229-241. See also Climate Accountability Institute, https://climateaccountability.org/index.html, for updated reports based on Heede's study.

${ }^{110} \mathrm{BP}$, alongside other major fossil fuel producers, was sued by property owners in Mississippi who claimed the companies' GHG emissions contributed to global warming and therefore to a rise in sea level that added to the ferocity of Hurricane Katrina, ultimately causing massive damage to claimants' property. See Comer v. Murphy Oil USA, 585 F.3d 855 ( $5^{\text {th }}$ Cir. 2009); Comer v. Murphy Oil USA, Inc., 839 F.3d 849 (S.D. Miss. 2012). Similarly, BP and other fossil fuel producers were defendants in the abovementioned case Kivalina. Both lawsuits were dismissed on procedural grounds.

${ }^{111}$ Mayor \& City Council of Baltimore v. BP p.I.c \& Others 388 F.Supp.3d 538 (D. Maryland 2019) (dismissing the argument that the 'City's claims "intrude upon both foreign policy and carefully balanced regulatory considerations at the national level, including the foreign affairs doctrine"' because the 'defendants [did] not actually identify any foreign policy that [was] implicated by the City's claims. The case was appealed, including the defendants motions to have it removed to a federal court; in March 2020, the US Court of Appeals for the Fourth Circuit allowed it to stay in state court); City of New York v. BP p.l.c. \& Others 325 F.Supp.3d 466 (S.D. New York 2018) (the claim was against the parent company only. The court held that 'to extent that city was seeking to hold companies liable for damages stemming, not just from domestic, but from foreign greenhouse gas emissions, city's claims were barred by presumption against extraterritoriality and need for judicial caution in face of serious foreign policy consequences'. As of March 2020, the case was under appeal in the US Court of Appeals for the Second Circuit); King County v. BP p.I.c.
} 
lawsuits focus not on the defendants own GHG emissions (as in American Electric Power Co. and Kivalina), but rather on their sale of fossil fuels to those who eventually burn them. ${ }^{112} \mathrm{BP}$ is also under investigation in the Philippines for the potential human rights violations resulting from climate change, with petitioners referring to the same studies. ${ }^{113}$ The investigation culminated in the Commission's announcement during UN climate negotiations in Madrid in December 2019, that based on the existing evidence, Carbon Majors could be found liable for human rights violations arising from climate change. ${ }^{114}$

Unlike the claims against the governments, such claims typically deploy compensation strategies, focussing on harms caused by allegedly tortious activities of private polluters. ${ }^{115}$ However, the circumstances in the abovementioned proceedings are quite different from Vedanta where the pollution was local and KCM was the only identifiable polluter. Meanwhile, climate change liability claims concern GHG emissions - pollution of exceptionally diffuse nature, caused by countless sources, and the causal chain between individual emissions and their contribution to climate change (particularly, extreme weather events attributed to it) is still not fully explored. ${ }^{116}$ As a result, claims against corporate emitters will most likely face formidable challenges, given 'a long latency period, diffuse harms affecting multiple victims, and diffuse origins from multiple tortfeasors'. ${ }^{117}$ Unsurprisingly, both BP and other non-US companies used this argument to challenge the lawsuits as well as the jurisdiction of the US courts since these companies are not

\& Others WL 4385447 (W.D. Wash. 2018) (the claim was against the parent company only. The court granted one of the defendants - RDS - motion to dismiss the claims against it due to the lack of jurisdiction); City of Oakland v. BP p.I.c. \& Others 325 F.Supp.3d 1017 (N.D. California 2018) (dismissing the claims on separation of powers and foreign policy grounds. As of March 2020, the case was under appeal in the Ninth Circuit); Rhode Island v. Chevron Corp. \& Others 393 F.Supp.3d 142 (D. Rhode Island 2019) (dismissing the argument that the foreign-affairs doctrine completely preempts the State's claims. As of March 2020, the case was under appeal in the US Court of Appeals for the First Circuit); Lawsuit City \& County of Honolulu v. Sunoco LP \& Others 1CCV-20-0000380 (Hawai'i Cir.Ct., filed in 2020).

112 See, for example, City of New York, at 473; City of Oakland, at 1024.

${ }^{113}$ Republic of the Philippines Commission on Human Rights In Re: National Inquiry on the Impact of Climate Change on the Human Rights of the Filipino People and the Responsibility therefor, if any, of the "Carbon Majors", Case No: CHR-NI-2016-0001, Memorandum for the Petitioners, 19 September 2019.

${ }^{114} \mathrm{CIEL}$, 'Groundbreaking Inquiry in Philippines Links Carbon Majors to Human Rights Impacts of Climate Change, Calls for Greater Accountability' (9 December 2019), available at https://www.ciel.org/news/groundbreaking-inquiry-in-philippines-links-carbon-majors-to-human-rightsimpacts-of-climate-change-calls-for-greater-accountability/. The Commission, however, is not a judicial body and its primary functions are investigatory and advisory. See A. Savaresi \& J. Auz, 'Climate Change Litigation and Human Rights: Pushing the Boundaries' (2019) 9(3) Climate Law, pp. 244-262, at 259-261.

115 However, claims against private emitters, following the model of litigation against the governments and demanding companies to substantially reduce their GHG emissions, are also starting to emerge. See nn 126-127 below.

${ }^{116}$ See, for example, P.A. Stott et al., 'Attribution of Extreme Weather and Climate-related Events' 2016 7(1) Wiley Interdisciplinary Reviews: Climate Change, pp. 23-41, at 30; S. Marjanac \& L. Patton, 'Extreme Weather Event Attribution Science and Climate Change Litigation: An Essential Step in the Causal Chain?' (2018) 36(3) Journal of Energy \& Natural Resources Law, pp. 265-298.

117 J. Todd, 'A "Sense of Equity" in Environmental Justice Litigation' (2020) 44(1) Harvard Environmental Law Review, pp. 169-233, at 181. See also D.A. Kysar, 'What Climate Change Can Do about Tort Law' (2011) 41(1) Environmental Law, pp. 1-71. 
incorporated in the states where they were sued. ${ }^{118}$ The argument that the abovementioned companies are not present in the US can be refuted fairly easily as demonstrated by the court in City of Oakland v. BP P.L.C.:

BP does not operate in California but several of BP's subsidiaries do. These subsidiaries produce oil and natural gas in California, own or operate port facilities in California to receive crude oil, ship crude oil from Alaska to California, license the ARCO trademark to gasoline stations in California, and promote gasoline sales through credit card offers and gasoline discounts. Elsewhere in the United States, BP subsidiaries produce fossil fuels, own refineries and pipelines, and market gasoline through BP-branded stores. ${ }^{119}$

Meanwhile, other challenges outlined above are typically countered by the findings in the abovementioned studies tracing the lion's share of cumulative worldwide GHG emissions to just 90 corporate entities (the so-called 'carbon majors') ${ }^{120}$ and the developments in attribution science, quantifying the anthropogenic climate change and related impacts ${ }^{121}$ as well as the evidence on deliberate public misinformation about the connection between burning of fossil fuels and climate change, perpetrated by the defendants. ${ }^{122}$ The precedential value of other types of environmental or public health litigation (especially, tobacco) against companies where claimants faced similar challenges is rightly pointed out as a strong argument supporting such liability claims against corporate emitters. ${ }^{123}$

Although it is yet to be determined how courts will treat all these findings in the context of corporate climate change liability, the experience from similar litigation abroad indicates that there is a possibility for such claims to go into evidentiary phase. For example, in German case Lliuya v. RWE $A G,{ }^{124}$ the claim was brought by a Peruvian citizen against a Germany-based energy company RWE in the District Court of Essen, asking to reimburse climate change adaptation costs in the claimant's village in Peru. The court dismissed the claim for lack of causality, but on the appeal, the Higher State Court of Hamm reversed this decision, allowing the case to move forward

\footnotetext{
${ }^{118}$ See, for example, Comer (2012), at 849; City of Oakland v. BP P.L.C. No. C 17-06011 WHA and No. C 1706011 WHA (N.D. Cal. 2018) (order granting motions to dismiss for lack of personal jurisdiction), at 5; King County v. BP p.I.c. at 9.

${ }^{119}$ City of Oakland v. BP P.L.C., n. 118 above, at 2.

${ }^{120}$ An important point here is that half of the emissions has been produced since 1986 (see Heede, n. 109 above, at 234); by that time, major fossil fuel companies were already aware about the risks associated with fossil fuel production and use (see n. 3 above).

${ }^{121}$ See D. Mitchell et al., 'Attributing Human Mortality During Extreme Heat Waves to Anthropogenic Climate Change' (2016) 11(7) Environmental Research Letters, pp. 1-8; B. Ekwurzel et al. 'The Rise in Global Atmospheric CO2, Surface Temperature, and Sea Level from Emissions Traced to Major Carbon Producers' (2017) 144(4) Climatic Change, pp. 579-590; R. Licker et al., 'Attributing Ocean Acidification to Major Carbon Producers' (2019) 14(12) Environmental Research Letters, pp. 1-14. For a comprehensive assessment of how climate change contribution science can be used in litigation see M. Burger, R. Horton \& J. Wentz, 'The Law and Science of Climate Change Attribution' (2020) 45(1) Columbia Journal of Environmental Law, pp. 57-240.

${ }^{122}$ See n. 3 above.

${ }^{123}$ See, for example, Ganguly, Setzer \& Heyvaert, n. 106 above, at 856-858. See also M. Olszynski, S. Mascher \& M. Doelle, 'From Smokes to Smokestacks: Lessons from Tobacco for the Future of Climate Change Liability' (2017) 30(1) Georgetown Environmental Law Review, pp. 1-45.

${ }^{124}$ Lliuya v. RWE AG, 20 285/15 (VG Essen, 2016).
} 
into the evidentiary phase. ${ }^{125}$ This stage involves the court reviewing expert opinion on the RWE's emissions and their contribution to climate change, including its impact on the claimant. An even more recent example is Smith v. Fronterra Co-Operative Group Limited ${ }^{126}$ in New Zealand, where a representative of indigenous Māori communities sued seven national companies that operate dairy farms, a power station, and an oil refinery and significantly contribute to GHG emissions in the country. ${ }^{127}$ The court, while rejecting the public nuisance and negligence claims, allowed the case to proceed to the trial, underscoring that its novel nature rendered it to be addressed on the merits. ${ }^{128}$ Neither of the two cases involve the parent-subsidiary relationship although their procedural significance is still very relevant. ${ }^{129}$

Furthermore, as seen from the recent legal action initiated by the French branch of the environmental NGO Friends of the Earth against French fossil fuel MNC Total SA, challenging a large-scale oil project in Uganda operated by its local subsidiary, ${ }^{130}$ climate change liability claims against the operations of MNCs in the host state though foreign subsidiaries are also becoming an issue for home state courts to address. The French case is particularly interesting as, under France's corporate duty of vigilance law, large French companies are obliged to publish annual plans that address the adverse impact of their activities, and those of subsidiaries and suppliers, on people and the environment. ${ }^{131}$ Although France's duty of care legislation is quite unique in the global corporate liability landscape, with climate change liability litigation experiencing a dramatic expansion in the last several years, ${ }^{132}$ it may just be a matter of time before such claims become widespread.

In that regard, the Supreme Court's decision in Vedanta offers an interesting opportunity, which is directly linked to the diffuse nature of GHG pollution and its cumulative effect. Foreign subsidiaries of the major emitting companies can produce significant emissions in the host states

\footnotetext{
${ }^{125}$ Lliuya v. RWE AG, 1-5 U 15/17 (Landgericht Essen, 2017).

${ }^{126}$ Smith v. Fronterra Co-Operative Group Limited \& Others [2020] NZHC 419 (High Court of New Zealand).

127 Notably, unlike in most other cases against fossil fuel companies, the claimant in this case is not seeking damages and instead, is requesting the court to have each defendant achieve net zero emissions by 2030 Ibid., paras 12-17. Another similar case, Milieudefensie et al. v. Royal Dutch Shell plc., initiated by a group of Dutch NGOs against RDS in April 2019 is currently pending in the Hague district court.

128 Smith, para. 103:

I am reluctant to conclude that the recognition of a new tortious duty which makes corporates responsible to the public for their emissions, is untenable. [I]t may be that a novel claim such as that filed by Mr Smith could result in the further evolution of the law of tort. It may, for example, be that the special damage rule in public nuisance could be modified; it may be that climate change science will lead to an increased ability to model the possible effects of emissions. These are issues which can only properly be explored at trial. I am not prepared to strike out the third cause of action and foreclose on the possibility of the law of tort recognising a new duty which might assist Mr Smith.

${ }^{129}$ For a discussion on the relevance of this case to the English law see V. Kumar \& W. Frank, 'Holding Private Emitters to Account for the Effects of Climate Change: Could a Case Like Lliuya Succeed under English Nuisance Laws?' (2018) 12(2) Carbon \& Climate Law Review, pp. 110-123.

130 Information about the action is available at https://www.totalincourt.org/?s=amisdelaterre.

${ }^{131}$ See Palombo, n. 69 above, at 275-6.

132 Though not necessarily involving the parent/subsidiary relationship and concerning different types of businesses.
} 
yet the host states themselves may still not be large scale emitters globally. ${ }^{133}$ Hence, even if the host states' courts were to hold these emissions by the subsidiaries negligible in the face of global emissions, ${ }^{134}$ the cumulative emissions of both the subsidiaries and their parent companies would likely be considerably higher, with their quantity and even approximated impacts much more palpable and calculable because of the abovementioned attribution studies. In practice, this means that claims against the subsidiaries (smaller emitters) alone could be less effective, as demonstrated in Smith, where the court expressed concern that since tortious liability is generally joint and several, it makes any defendant against whom a claim is made potentially 'liable for the whole of a plaintiff's loss, notwithstanding the individual defendants' minimal contribution to the global emissions that, combined, have caused climate change'. ${ }^{135}$ Therefore, a prospective claim against both the foreign subsidiary and the parent company brought in the parent company's home state could be more viable. ${ }^{136}$

Admittedly, such an approach would still not eliminate all the challenges. For example, in Smith, the court hypothesized that '[r]ecognising the duty claimed would give rise to issues of indeterminate liability on anyone' and 'the class of potential defendants is equally openended' ${ }^{137}$ The court in Oakland reasoned along very similar lines:

While these actions are brought against the first, second, fourth, sixth and ninth largest producers of fossil fuels, anyone who supplied fossil fuels with knowledge of the problem would be liable. [...] Everyone has contributed to the problem of global warming and everyone will suffer the consequences. ${ }^{138}$

Of course, it would be wrong to view these challenges as insurmountable; for example, climate change is recognized to be disproportionately affecting developing countries as well as vulnerable communities in the developed countries, whose contribution to global emissions is far lower than

\footnotetext{
${ }^{133}$ This is especially true in case of countries with a significant presence of foreign fossil fuel corporations, including Nigeria and the Philippines. See Heede, n. 109 above, at 231.

${ }^{134}$ The alleged negligible contribution to cumulative emissions is a common argument in climate change litigation; it was refuted by both the Supreme Court of the Netherlands in Urgenda, para. 5.7.8 (ruling that ' $[\mathrm{t}]$ he defence that a duty to reduce greenhouse gas emissions on the part of the individual states does not help because other countries will continue their emissions cannot be accepted [...]: no reduction is negligible', and the US Supreme Court in Massachusetts, at 525-526 (holding that the existence of other major GHG emitters like China and India, should not preclude the US agency from its regulatory duty, because '[a] reduction in domestic emissions would slow the pace of global emissions increases, no matter what happens elsewhere'). Some other courts, however, have ruled differently. For a discussion see $\mathrm{S}$. Varvastian, 'Access to Justice in Climate Change Litigation from a Transnational Perspective: Private Party Standing in Recent Climate Cases', in J. Jendrośka \& M. Bar (eds), Procedural Environmental Rights: Principle $X$ of the Rio Declaration in Theory and Practice (Intersentia, 2017) pp. 481-502.

${ }^{135}$ Smith, para. 98.

${ }^{136}$ The fact that such lawsuits could be brought by those affected by climate change in the developing world raises, among other things, the question of climate justice. See J. Peel \& J. Lin, 'Transnational Climate Litigation: The Contribution of the Global South' (2019) 113(2) American Journal of International Law, pp. 679-726, at 681; J. Setzer \& L. Benjamin, 'Climate Litigation in the Global South: Constraints and Innovations' (2020) 9(1) Transnational Environmental Law, pp. 77-101.

137 Smith, para. 98.

${ }^{138}$ City of Oakland v. BP P.L.C., (order granting motion to dismiss amended complaints), n. 118 above, pp. 6 and 12.
} 
that of their counterparts, ${ }^{139}$ thus highlighting a critical flaw in the reasoning of the district court in Oakland. Furthermore, as the Ninth Circuit recently confirmed in the climate change case against the US federal government Juliana $v$. United States, the presence of multiple links in the causal chain does not preclude from establishing causation, ${ }^{140}$ although dismissing it for the alleged lack of redressability. ${ }^{141}$

Overall, arguments against allowing climate change liability cases against private emitters to be decided on the merits may be dictated more by political reasons rather than legal or scientific ${ }^{142}$ and it is no secret that claimants in such cases face an uphill battle. Therefore, there is no reason for them not to explore those options that could potentially alleviate it. It is difficult to predict whether a prospective climate change liability claim based on Vedanta could succeed in England or elsewhere. However, the fact that it is possible, and that the Supreme Court's decision in Vedanta seemingly indicates that English courts could have jurisdiction to hear such claims, may open an entirely new chapter in the climate change liability litigation against private GHG emitters.

\section{Concluding remarks}

Just one month after the UK Supreme Court's decision in Vedanta, the Zambian government announced its plans to seize control of KCM's assets. ${ }^{143}$ If these plans materialize, it would be questionable whether the case could progress to the merits stage. Ironically, this situation corroborates the Supreme Court's reflections on the 'disproportionate way in which these jurisdiction issues have been litigated' ${ }^{144}$ Indeed, it took nearly four years of litigation, nearly 300 pages of written cases and nearly 9,000 pages of electronic documents ${ }^{145}$ as well as going all the way from the court of first instance to the Supreme Court to resolve the question of jurisdiction, which may now be of little practical use for the claimants. Interestingly, in its considerations on whether Zambia would be a proper forum to try the matter, the High Court also anticipated a

\footnotetext{
${ }^{139}$ See OHCHR Report of the Special Rapporteur on the issue of human rights obligations relating to the enjoyment of a safe, clean, healthy and sustainable environment (No. A/74/161) (2019), available at http://www.srenvironment.org/sites/default/files/Reports/2019/UNGA\%20Safe\%20Climate\%20Report\% 202019.pdf.

${ }^{140}$ Juliana v. United States, 947 F.3d 1159, 1169 (9 g $^{\text {th }}$ Cir. 2020)

${ }^{141}$ Ibid. at $1169-1175$.

${ }^{142}$ See K. Fischer Kuh, 'Judicial Climate Engagement' (2020) 46 (forthcoming) Ecology Law Quarterly. See also M. Burger, R. Horton \& J. Wentz, n. 121 above, at 141, noting that attribution science is not always effective at persuading courts to take action on climate change - not only due to the 'complexity and limitations in the science' but also due to political barriers.

${ }^{143}$ See T.C. Mitimingi \& M. Hill, 'Zambia Files Notice of Plans to Seize Vedanta Copper Assets' (20 May 2019), available at

https://www.bloomberg.com/news/articles/2019-05-20/zambia-files-notification-of-plans-to-take-overvedanta-assets. The decision is being implemented through a petition that has been filed in the Zambian High Court by ZCC-IH to liquidate KCM. See C. Phiri, 'KCM Placed under Liquidation' (21 May 2019), available at https://zambiareports.com/2019/05/21/kcm-placed-liquidation/.

144 Vedanta, para. 6.

145 Ibid., para. 10.
} 
similar scenario when it theorized that Vedanta may liquidate KCM in order to avoid paying out claims if it lost the trial in Zambia. ${ }^{146}$

Still, the relevance of the decision cannot be understated. While it may not necessarily open the floodgates for environmental and climate change claims against English companies given their costs and other constraints, Vedanta is an important precedent for providing access to justice for foreign claimants in transnational corporate liability litigation. ${ }^{147}$ In the wake of this decision, at least some English companies may revise their policies and responsibilities for the maintenance of standards of environmental control over the activities of their foreign subsidiaries to avoid prospective lawsuits. It can only be hoped for that such revisions would require the foreign subsidiaries to exercise due diligence ${ }^{148}$ and not, on the contrary, create an illusory distance between them and the parent companies in order to shield the latter from liability. That said, it must also be acknowledged that even in case of successful outcome, litigation in the English, or other developed countries' courts would not solve the underlying problems that claimants in the developing countries like Zambia or Nigeria face. It would not bolster the expertise within the legal circles, nor the enforcement in these countries. However, it can be critical in achieving justice - something indispensable to those, who for various reasons were forsaken by both their national institutions and the international community.

\footnotetext{
${ }^{146}$ Lungowe, para. 79.

147 See, for example, Curran, n. 60 above, at 443, arguing that Vedanta and other similar cases in the common law jurisdictions could also be taken into account by the US courts, to a more extent than cases in civil law jurisdictions.

${ }^{148}$ See Sherman, n. 70 above, at 29.
} 